\title{
PLASMA FLUORIDE LEVELS FOLLOWING OBSTETRICAL USE OF METHOXYFLURANE
}

\author{
R.J. Palahniux and M. Cumming
}

\section{INTRODUCTION}

Methoxyflunane continues to be a valuable analgesic and anaesthetic agent for obstetrical patients despite the nephrotoxicity associated with its use. This renal impairment is directly related to the accumulation of inorganic fluoride ion, a product of methoxyflurane metabolism. The plasma fluoride level is related to the "dose" of methoxyflurane administered and correlates with the clinical and biochemical evidence of nephrotoxicity. This study was undertaken to assess the safety of methoxyflurane by determining plasma fluoride levels in three groups of obstetrical patients:

(a) those who receive methoxyflurane for delivery only

(b) those who receive methoxyflurane for labour and delivery, and

(c) those to whom methoxyflurane is administered for Caesarean section.

\section{METHOD}

Methoxyflurane was administered to patients undergoing labour and delivery or Caesarean section. Patients with a history of pre-existing renal disease, severe pre-eclampsia or severe systemic illness were excluded from the study. Patients were selected only according to their requirement for inhalation analgesia and/or anaesthesia as determined by the anaesthesiologist on the labour floor. No attempt was made to influence the duration or technique of administration so that the results would indicate the possible dangers associated with the normal clinical use of methoxyflurane. Many of the patients studied also received meperidine either alone or with added phenothiazines, early in labour. The patients were divided into three groups on the basis of technique of methoxyflurane administration.

\section{A. Delivery Group}

Fifty patients received methoxyflurane analgesia for delivery only. Methoxyflurane was delivered in concentrations of 0.2 to 0.5 per cent in nitrous oxide (50 to 70 per cent) or in oxygen alone. The anaesthesia was administered using a standard circle system and a Pentec ${ }^{\circledR a p o r i z e r, ~ w i t h ~ t o t a l ~ f l o w ~ r a t e s ~ o v e r ~} 6$ litres per minute.

\section{B. Labour and Delivery Group}

Forty-one patients received methoxyflurane during the late first stage as well as

Departments of Anaesthesia and Obstetrics and Gynaecology, University of Manitoba and Health Sciences Centre, Winnipeg, Manitoba. 
during the second stage of labour. Analgesia during the first stage was usually self-administered, using a Cyprane inhaler at the middle setting (5/9). The delivered concentration of methoxyflurane would then have been about 0.3 per cent. ${ }^{2}$ For delivery, the analgesia was administered using the anaesthetic machine as described above.

\section{Caesarean Section Group}

Fourteen patients received methoxyflurane during their Caesarean section anaesthetic. Methoxyflurane was administered in 0.2 to 0.5 per cent concentrations from a Pentec vaporizer and added to nitrous-oxide (50 per cent to 70 per cent) and oxygen ( $30-50$ per cent). Eight of these patients received methoxyflurane prior to delivery while six had it added to their anaesthetic only after the baby was delivered. In all cases, anaesthesia was induced with thiopentone, the trachea was intubated and ventilation was controlled.

In addition, one case which did not fit into any of these groups will be described as a separate case report.

Fluoride concentration was measured using the ion-specific fluoride electrode. ${ }^{3}$ In all groups, plasma inorganic fluoride levels were determined in maternal venous blood prior to the administration of methoxyflurane (i.e. control level), at delivery, two hours after the termination of administration, and twenty-four hours after administration.

The Caesarean section group also had a determination at the end of the operation. Foetal inorganic fluoride levels were determined in umbilical venous blood obtained from a double-clamped cord segment obtained at delivery. All blood samples were heparinized and the plasma frozen as soon after collection as possible.

Most of the neonates were weighed at delivery and at 24 hours of age. The clinical condition of the neonates was inferred from the Apgar score at one and five minutes after delivery.

The results were analysed using a Student's t-test for paired data with $p<0.05$ used as the level of significance.

\section{Results}

The duration of methoxyflurane administration is shown in Table I. The exposure tended to be relatively short as it is not our practise to administer inhalation analgesia throughout first stage, but rather only when the cervix is nearing complete dilation.

Plasma inorganic fluoride levels are illustrated in Figures 1,2 and 3 and in Table II. There was statistically significant rise in plasma inorganic fluoride at all times in each group. In general, the longer the duration of exposure, the higher the plasma fluoride level. The foetal (cord) level was about one-half the maternal venous level at delivery in each group.

Neonatal weight loss in the first 24 hours was less than five ounces in each group, no infant showing a weight loss greater than eight ounces. There were eight neonates with one minute Apgar scores of six or less. In all cases there were obstetrical factors to explain the depression, and none were judged to be depressed as a result of the inhalation analgesia alone. All five minute Apgar scores were seven or more. 
PALAHNIUK \& CUMMING: PLASMA FLUORIDE LEVELS

TABLE I

Duration of Methoxyflurane Exposure in Minutes \pm S.D.

\begin{tabular}{lcc}
\hline & \multicolumn{1}{c}{ Mean } & Range \\
\hline A. Delivery only & $19.7 \pm 5.9$ & $4-41$ \\
B. Labor and Delivery & $49.1 \pm 23.9$ & $18-120$ \\
C. Caesarean Section & $39.6 \pm 14.2$ & $23-75$ \\
\hline
\end{tabular}

TABLE II

Plasma Inorganic Fluoride Level.s $\mu \mathrm{mol} / 1 \pm$ S.D.

\begin{tabular}{lccr}
\hline \hline & $\begin{array}{c}\text { Delivery } \\
\text { Group }\end{array}$ & $\begin{array}{c}\text { Labour and } \\
\text { Delivery } \\
\text { Group }\end{array}$ & $\begin{array}{c}\text { Caesarean } \\
\text { Section } \\
\text { Group }\end{array}$ \\
\hline 1. Control & $\mathbf{1 . 6 \pm 0 . 1}$ & $1.5 \pm 0.1$ & $\mathbf{1 . 6 \pm 0 . 2}$ \\
2. Delivery & $5.9 \pm 0.4$ & $10.2 \pm 0.1$ & $6.1 \pm 1.4$ \\
3. End of Operation & $-5 \pm 0.4$ & $9.5 \pm 1.3$ & $\begin{array}{r}17.9 \pm 1.9 \\
\text { 4. 2 Hours }\end{array}$ \\
5. 24 Hours & $5.3 \pm 0.9 \pm 2.1$ \\
6. Cord Blood & $2.8 \pm 0.2$ & $5.1 \pm 1.3$ & $10.9 \pm 1.3$ \\
\hline
\end{tabular}

TABLE III

Mrs. M.W. Plasma Fluoride $\mu \mathrm{mol} / 1$

\begin{tabular}{lcc}
\hline & Maternal & Cord \\
\hline 1. Control & 2.1 & - \\
2. Delivery twin A & - & 13.5 \\
3. Delivery twin B & 73.4 & 18.1 \\
4. 2 Hours & 50.3 & - \\
5.24 Hours & 52.4 & - \\
\hline
\end{tabular}

\section{CASE Report}

Mrs. M.W. was a 25-year-old gravida 1 paca o with a twin pregnancy. She was healthy, on no prior medications, and had never had an anaesthetic.

She used the Cyprane inhaler for 30 minutes during late first stage and then was given 20 minutes of inhalation analgesia with methoxyflurane-oxygen for the delivery of twin $A$. When twin B was found to have a prolapsed umbilical cord, anaesthesia was induced rapidly, the trachea was intubated and anaesthesia was maintained using methoxyflurane-oxygen for the forceps delivery of twin B (20 minutes) and methoxyflurane, nitrous-oxide and oxygen for the repair of the perineal laceration ( 35 minutes). The total time of methoxyflurane administration was then 105 minutes with delivered concentrations up to 0.8 per cent. Maternal and foetal plasma inorganic fluoride levels are shown in Table III.

\section{Discussion}

Methoxyflurane has a number of properties which make it a particularly popular agent for use in obstetrics. To date, no other volatile anaesthetic has proven to be 


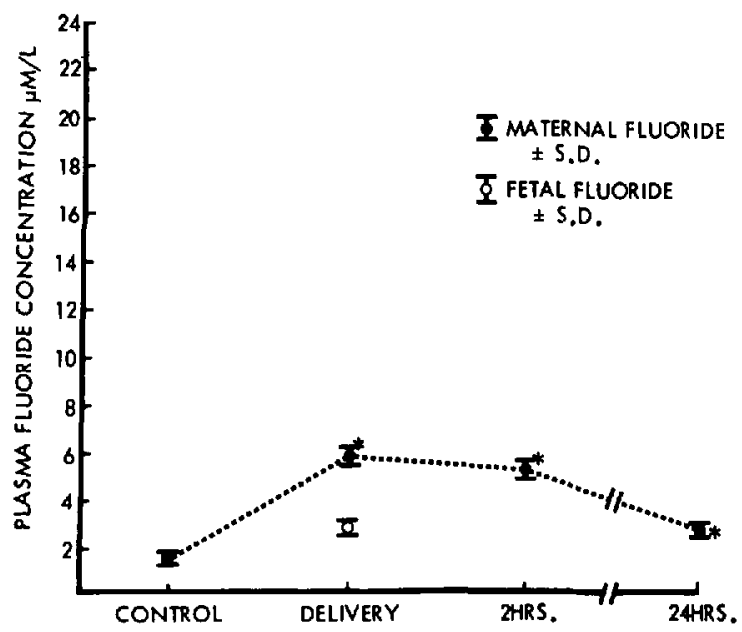

Figune 1. Plasma fluoride levels following methoxyflurane analgesia for delivery only. ${ }^{\circ}=$ significant change from control.

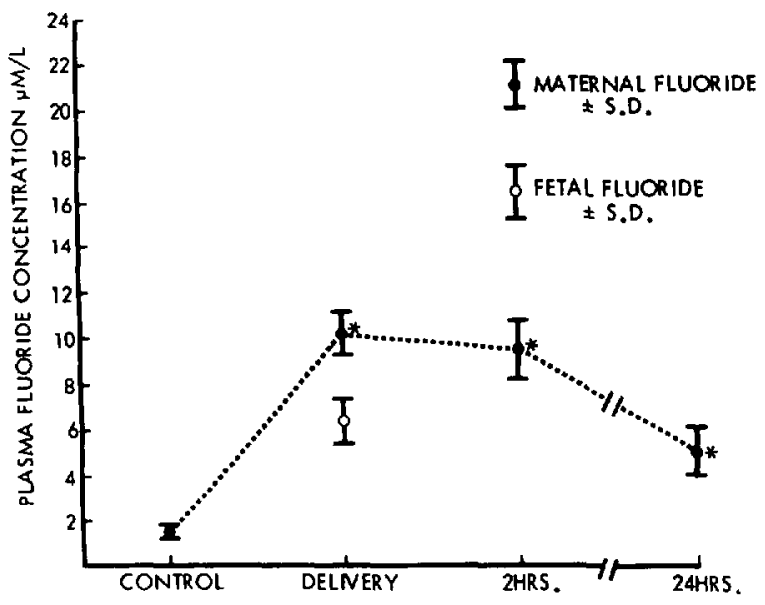

Ficure 2. Plasma fluoride levels following methoxyflurane analgesia for labour and delivery. $\bullet=$ significant change from control. 


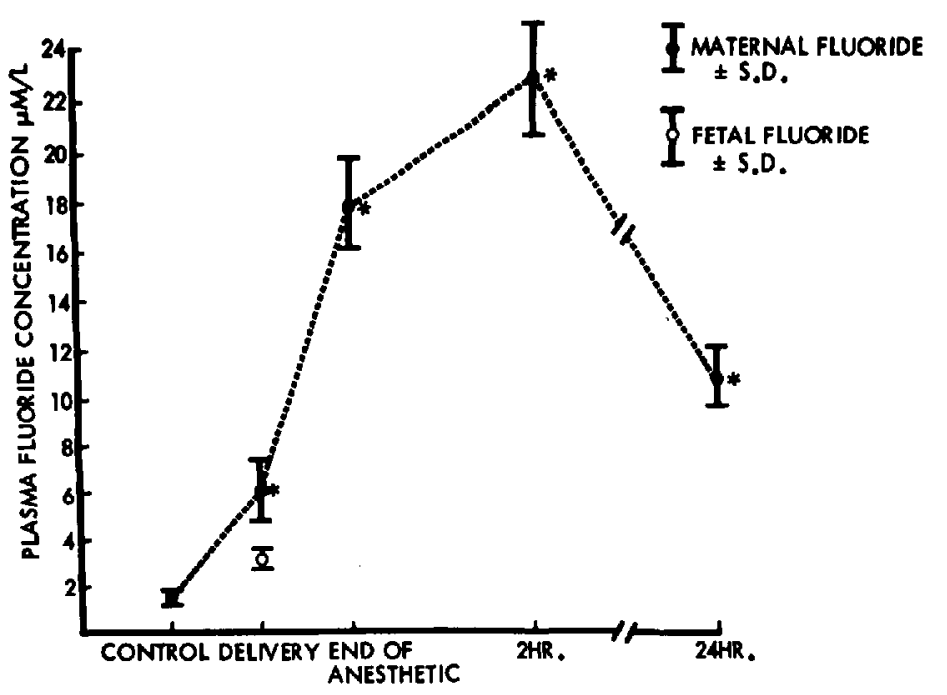

Figure 3. Plasma fluoride levels following methoxyflurane use at Caesarean section. : = significant change from control.

a suitable replacement, explaining the continued extensive use of methoxyflurane in obstetrics. Following the first reports of methoxyflurane nephrotoxicity, ${ }^{6,7}$ correlation of renal function with serum inorganic fluoride levels has been demonstrated in man, ${ }^{1,8}$ and the renal lesion has been duplicated in animals by the administration of inorganic fluoride. ${ }^{9}$ In addition, Cousins and Mazze correlated time and dose of methoxyflurane in MAC-hours with inorganic fluoride levels, and this with nephrotoxicity, to show that the threshold for renal impairment is about 2.5 MAC hours. ${ }^{10}$ They have also determined that the threshold inorganic fluoride level for biochemical renal impairment is about $50 \mu \mathrm{mol} / \mathrm{l}$ with clinical high output renal failure becoming evident at $100 \mu \mathrm{mol} / \mathrm{l}$.

In obstetrics, Rosen was unable to demonstrate any renal dysfunction following methoxyflurane analgesia in 125 patients. ${ }^{11}$ More recently several investigators have measured serum inorganic fluorides levels following methoxyflurane analgesia. ${ }^{12,13,14}$ None of them found levels which were alarmingly high. In particular Creasser studied 24 women who received methoxyflurane for labour and delivery with a mean duration of administration of over two hours and found a mean peak inorganic fluoride level of $21.9 \mu \mathrm{mol} / 1$ with the highest level recorded being 62 $\mu \mathrm{mol} / \mathrm{l}$ following over four hours exposure. Other laboratory investigation in these patients and their neonates failed to demonstrate any evidence of renal dysfunction.

In the present study, mean plasma inorganic fluoride levels were not excessively high in any group. In isolated cases, however, the plasma fluoride levels may reach high levels as in the one case illustrated here with a peak inorganic fluoride of $73.4 \mu \mathrm{mol} / \mathrm{l}$.

The patients who received methoxyflurane as a supplement to Caesarean section are of particular interest since methoxyflurane is being recommended to prevent maternal awareness at Caesarean section. ${ }^{16,16}$ In our group, methoxyflurane was administered at low concentrations for up to 75 minutes but the mean peak 
fluoride level was only $22.9 \mu \mathrm{mol} / 1$ with the highest level $33.7 \mu \mathrm{mol} / 1$ - well within the safe range.

The umbilical venous fluoride levels give an indication of the placental transfer of fluoride and/or foetal metabolism of methoxyflurene. Until we have a better idea of the foetal renal sensitivity to fluoride, however, the safety of methoxyflurane for the foetus can only be speculative, although there has been no evidence that any neonate has suffered renal impairment following methoxyflurane administration to the mother.

\section{SUMMARY}

Plasma fluoride levels were measured in 106 patients undergoing labour and delivery or Caesarean section. Mean plasma fluoride levels in all groups of patients studied were well below the levels expected to produce renal impairment. In one case with probable excessive methoxyflurane use, plasma fluoride level reached $73.4 \mu \mathrm{mol} / \mathrm{l}$. Umbilical venous fluoride levels were about one-half the mother's venous level at delivery.

\section{RÉSUMÉ}

Les niveaux plasmatiques de fluorures ont été mesurés chez 106 patientes au cours du travail et de l'accouchement ou de la césarienne. Dans tous les groupes de patientes étudiées, les niveaux moyens de fluorures plasmatiques étaient bien inférieurs aux niveaux susceptibles de provoquer une déficience rénale. Cependant dans un cas où l'emploi de méthoxyflurane semble avoir été excessif, le niveau plasmatique de fluorures a atteint $73.4 \mu \mathrm{mol} / \mathrm{l}$. Les taux de fluorures dans la veine ombilicale étaient d'environ la moitié de ceux trouvés dans le sang de la mère au moment de l'accouchement.

\section{ACKNOWLEDGMENTS}

The authors would like to thank Mrs. Maureen Burnham and Mrs. Darlene Evaniuk for technical and secretarial assistance. They would also like to thank Abbott Laboratories, North Chicago, U.S.A., for their support in conducting this study.

\section{REFERENCES}

1. Mazze, R.I., Trudell, J.R., \& Cousins, M.J. Methoxyflurane metabolism and renal dysfunction: clinical correlation in man. Anesthesiology 35: 247 ( 1971 ).

2. Holl, J.W. \& SHnider, S.M. Methoxyflurane concentration from the Cyprane inhaler. Anesthesiology 28: 770 ( 1967 ).

3. Fry, B.W. \& TAves, D.R. Serum fluoride analysis with the fluoride electrode. J. Lab. Clin. Med. 75: 1020 (1970).

4. Paddock, R.B., Parker, J.W., \& Guadagni, N.P. The effects of methoxyllurane on renal function. Anesthesiology 25: 708 (1964).

5. Crandell, W.B., Pappas, S.G., \& MacDonald, A. Nephrotoxicity associated with methoxyflurane anesthesia. Anesthesiology 27:591 (1966). 
6. Mazze, R.I., Shue, G.L., \& Jackson, S.H. Renal dysfunction associated with methoxyflurane anesthesia: a randomized prospective clinical evaluation. J.A.M.A. 216: 278 (1971).

7. Austin, W.H. \& Villandry, P.J. Methoxyflurane and renal function. Anesthesiology 28: 637 (1967).

8. Taves, D.R., Fry, B.W., Freeman, R.B., \& Gilles, A.J. Toxicity following methoxyflurane anesthesia II. Fluoride concentration in nephrotoxicity. J.A.M.A. 214: 91 (1970).

9. Mazze, R.I., Cousins, M.J., \& Kosex, J.C. Dose-related methoxyflurane nephrotoxicity in rats: a biochemical and pathologic correlation. Anesthesiology $36: 571$ (1972).

10. Cousins, M.J. \& Mazze, R.I. Methoxyflurane nephrotoxicity. A study of dose response in man. J.A.M.A. 225: 1611 (1973).

11. Rosen, M., Latto, P., \& Asscher, A.W. Kidney function after methoxyflurane analgesia during labour. Brit. Med. J. 1: 81 ( 1972 ).

12. Hetruch, W.D., Wolfsen, B., Garcia, D.A., \& Siker, E.S. Renal responses to light methoxyflurane anesthesia. Anesthesiology 38: 30 (1973).

13. Fry, B.W. \& TAves, D.R. Maternal and fetal flurometabolite concentrations after exposure to methoxyflurane. Am. J. Obstet. Gynecol. 119: 199 ( 1974).

14. Creassen, C.W., Stoelting, R.K., Krishna, G., \& Petersen, C. Methoxyflurane metabolism and renal function after methoxyflurane analgesia during labour and delivery. Anesthesiology $41: 62$ (1974).

15. Latto, I.P. \& Wainwricht, A.C. Anaesthesia for Caesarean section. Analysis of blood concentration of methoxyflurane using 0.1 per cent methoxyflurane and 40 per cent oxygen. Br. J. Anaesth. 44: 1050 ( 1972 ).

16. Houle, G.L., Fox, G.S., \& Gertel, M. Methoxyflurane: clinical and laboratory studies during Caesarean section. Anesth. Analg. Curr. Res. 48: 1011 (1969). 